\title{
Unconventional Expansionary Monetary Policies. An Economic Analysis of Quantitative Easing
}

\author{
Jordi Franch Parella \\ University of Vic - Central University \\ Catalonia (UVic-UCC) \\ Spain
}

\begin{abstract}
Expansionary monetary and fiscal policies followed the 2008 great recession. The Federal Reserve, and the main central banks, responded with severe cuts of the interest rate in response to the emerging economic distress. With interest rates in the lower bound, productivity has not recovered its past trend. Quantitative Easing is an ultra expansionary monetary policy whereby a central bank buys government bonds and private sector assets in order to stimulate the economy. Although this process temporarily could relieve the governments, gaining time to implement structural reforms, it has eventually created a debt bubble that impairs the economic performance. Financial asset prices have risen indiscriminately, having adverse consequences for the distribution of wealth. At the end, printing money does not mean creating growth and debt accumulation, money creation, unfunded liabilities and malinvestments continue unabated threatening the immediate future of the global economy. The overall balance of $Q E$ is very disappointing.
\end{abstract}

Keywords: quantitative easing, money, inflation, monetary policy, central bank

JEL Classification: E40, E43, E50, E51, E52, E58

\section{Introduction}

The onset of the 2008 crisis in the real economy was preceded by turmoil in the financial markets. Lehman Brothers filed for bankruptcy on 15th September and the economy went into serious recession. Economic stimulating policies, both monetary and fiscal, followed the great recession. The Federal Reserve, and the rest of the main central banks, responded with severe cuts of the interest rate in response to the emerging economic distress (Bernanke, 2009; Bullard, 2009). From the value of 5.25\% in the middle of 2007, the Federal Open Market Committee lowered the rate to effectively zero. In August 2007, the Federal Reserve started to implement extraordinary monetary policy measures such as lowering collateral quality requirements and large open market operations. The first implementation of Quantitative Easing (QE) took place in U.S. in November 2008 when the Fed spent $\$ 600$ billion on the purchase of mortgage-backed securities. QE involves a large-scale asset purchase. It is an ultra expansionary monetary policy whereby a central bank buys government bonds and other financial assets in order to stimulate the economy (Bank for International Settlements, 2017; Feldstein, 2016). It has been used when standard monetary policy has become ineffective. When central banks purchase financial assets mainly from commercial banks, the price of those assets rise and the yield lowers, while money supply is increased. That differs from standard monetary policy of buying or selling short-term government bonds in order to lower shortterm interest rates. The limit of standard expansionary monetary policy is when short-term market interest rates approach zero (Bernanke and Reinhart, pp. 85-90), what is known as the liquidity trap (Auerbach and Obstfeld, 2005). In such circumstances, QE tries to stimulate the economy by buying long-term and riskier assets, such as mortgage backed securities and corporate bonds, increasing their price and reducing interest rates further out on the yield curve. Purchases of financial assets were halted in U.S. on October 2014 after the Fed accumulated $\$ 4.5$ trillion in assets. The unprecedentedly low federal funds rate has remained to this day. In January 2018, Janet Yellen handed the reins to Jerome Powell. The Federal Reserve raised the target range for the federal funds rate by a quarter point to 1.5-1.75 percent during its March 2018 meeting. The Fed officials also projected a steeper path of hikes in 2019 and 2020. The interest rate in the United States averaged 5.7 percent from 1971 until 2018, reaching an all-time high of 20 percent in March 1980. 


\section{The nature of $Q E$}

Conventional expansionary monetary policies entail lowering the short-term interest rate and increase the quantity of money in circulation through the buying of treasury bills, in exchange for money on deposit at the central bank. As those deposits are convertible to currency, these purchases result in more base currency entering market circulation. When commercial banks have more money to lend they reduce lending rates (Eggertsson and Woodford, 2003 and 2004), making loans less expensive. With more and cheaper loans affordable, companies should expand and consumer spending should also boost. More workers should be hired, rising income and increasing demand. QE or unconventional expansionary monetary policies go much further. When interest rates are near or at zero percent, and there are concerns about deflation or low inflation, central banks purchase longterm government bonds and private sector assets to improve liquidity and facilitate access to credit. QE tries to stimulate the economy not only by lowering short-term interest rates, but by buying long-term riskier assets, increasing their price and reducing long-term interest rates (Summers, 2014). Central banks also try to influence real long-term interest rates by impacting on market expectations. That's to say, the central bank can lower the real interest rate if it can induce the public to expect a higher price level in the future. With a higher expected inflation, the real interest rate falls even if the nominal interest rate remains unchanged at the lower bound. If the management of expectations is successful, the reduction in the real long-term interest rate should foster borrowing and aggregate demand. In any case, as Japan has demonstrated (Bernanke, 2003; Caballero et alter, 2008), the difficulties of turning around expectations of prices and economic activity, when the functioning of the financial system is impaired, are enormous. QE will only affect expected inflation if the increase in the size of the central bank's balance sheet is both sizeable and permanent. And, even in case of affecting expectations, it should also be recognised that a government bond purchasing programme involves the risk of significant losses for the central bank. The economic recovery will entail an increase in long-term interest rates. This will bring down government bond prices, so that the central bank and the commercial banks -always important government bond holders- will face significant losses (Reinhart and Rogoff, 2014).

Since 2007, the Federal Reserve's balance sheet expanded from about $\$ 890$ billion to more than $\$ 4.5$ trillion. Somewhat similar in Europe. The European Central Bank embarked on QE in March 2015, raising the monthly amount for asset purchases from $€ 60$ billion to $€ 80$ billion, expanding the range of assets to include corporate bonds. With QE, the central banks of the world have increased their balance sheet by $\$ 8.3$ trillion, with only $\$ 2.1$ trillion worth of GDP growth to show for it. This has left $\$ 6.2$ trillion of excess liquidity in the banking system that is not where the economic planners had guessed. And now central banks own more than $\$ 10$ trillion of negative interest yielding bonds. QE monetary policy has created a bubble economy of enormous size which one day will burst. This process temporarily could aid the economy (Haldane et alter, 2016), but structural defects multiply at the end. Money creation, debt accumulation, unfunded liabilities, malinvestments, public benefits, wars, uncontrolled government growth, and systematic attacks on our liberties, have continued unabated. At the end, debt is not wealth, paper is not money, free stuff is not justice, war is not peace, and government coercion is not liberty. Prosperity built on inflation and debt is a mirage that cannot last (Paul, 2007).

QE arises inequitable wealth distribution. The wealthy get wealthier and the poor get poorer. The wealthy and well-connected to the banking system benefit from inflation and $\mathrm{QE}$, because they are the first to receive the newly created money. But down the socio-economic pyramid, the effects are more adverse, as money begins circulating and loses value. At the end, a certain strata of society are protected: the financial sector and those connected to it. Everyone else, is impoverished by the system, and what is worse, becomes dependent on it (Lacalle, 2014). The reasons of inequity, not being understood, cause those who feel cheated to become angry. Populist extremist parties present one of the most pressing challenges to democracies. Across Europe, for instance, the centre-left social democrats and centre-right Christian democrats who have dominated national politics for many years are in decline. Traditional mainstream parties are undeniably in full retreat. What is on the march across Western countries is distrust, disillusion and rejection of the political establishment. This conflict encourages the flourishment of envy and greed, contributing to the moral decay of the society.

\section{Evaluation of QE objectives}

The declared objective of $\mathrm{QE}$ is to mitigate the economic problems since the crisis through an expansion of private bank lending. The central banks maintain interest rates at a lower than usual rate and increase the total supply of money in the economy to combat the recession. By artificially lowering interest rates, central banks pretend that cheap and abundant credit will entice businesses into expanding. 
The increase in aggregate demand, i.e. the overall demand for all goods and services in an economy, should boost short-term growth measured by Gross Domestic Product. QE or ultraexpansionary monetary policies also reduce the value of the currency relative to other currencies. QE was launched with four main objectives: provide liquidity to reduce the risk of contagion after the financial crisis, stimulate inflation to a benchmark near $+2 \%$, generate growth and create jobs.

\subsection{Liquidity}

The first objective was achieved, but at the expense of bailing out some countries and many bad banks. It does create economic imbalances as well as social inequalities. Clearly, it does also create moral hazard through the assurance of safety nets and it signals to the firms that they can take reckless risks and that taxpayers will pay the losses. Furthermore, it promotes centralized bureaucracy by allowing government powers to choose the conditions of the bailout. As American Republican Congressman Ron Paul wrote, "In bailing out failing companies, they are confiscating money from productive members of the economy and giving it to failing ones. By sustaining companies with obsolete or unsustainable business models, the government prevents their resources from being liquidated and made available to other companies that can put them to better, more productive use. An essential element of a healthy free market is that both, success and failure, must be permitted to happen when they are earned. But instead, with a bailout, the rewards are reversed -the proceeds from successful entities are given to failing ones. It is obvious to most that we need to reject corporate cronyism, and allow the natural regulations and incentives of the free market to pick the winners and losers in our economy, not the whims of bureaucrats and politicians." 1

\subsection{Inflation}

In terms of inflation, with money velocity collapsing and low capacity utilization, massive monetary stimulus has been disinflationary (Franch, 2018). The commercial banks have chosen to hold the liquidity in exchange for the bonds in their reserves at the central bank as a buffer. Therefore, the liquidity provided by the central bank remains within the financial sector and does not flow out of it. Inflation measured by the CPI is subdued, but many other bubbles arise as a consequence of creating trillions of dollars out of thin air. For instance, and to name but a few, the returning housing bubble, the stock market and the bond market. Indeed, the enormous creation of money has gone to create huge inflation in financial assets with stocks at all-time highs, and the largest debt bubble in financial history. While world trade has fallen to 2010 levels, rise in government debt as a percentage of GDP between 2007 and 2016 has risen from 64 percent to 107 percent in United States, from 65 percent to 89 percent in Eurozone, from 183 percent to 230 percent in Japan and from 35 percent to 45 percent in China. The largest bubble in bonds ever seen was created, with more than $\$ 11$ trillion of bonds issued at the lowest rate (Bank for International Settlements, 2017). That involves a social problem of income distribution between the first receivers of the new money created and the last receivers. The first ones -basically the financial and political elitsget a benefit of monetary stimulus, while the last ones -workers, pensioners and savers of all kinds- worsen their standing. Quantitative easing punishes savers, by driving down interest rates, while it rewards borrowers. This paradox may help explain features of our time, such as the drop in popular satisfaction with the direction of many countries, and the increasing attraction of extremist voices in electoral politics. That causes social unrest. The weakened middle class, whose wages have declined for decades, seeks social justice through populist movements. The quantitative easing monetary disruption almost certainly has contributed to the protest votes that have been observed in the Western world. The rise in asset prices will make citizens, only the owners, feel richer. It's the elusive "wealth effect." The type of money the Fed has been creating is called reserves, that's to say, money held by commercial banks in the accounts at the central bank. In some circumstances, increasing reserves can lead banks to lend more to the public. But this time, because of the high level of indebtedness, economic agents have preferred not to increase the already high level of leverage.

\subsection{Growth}

In terms of growth, a poor record has been achieved. QE has not given the U.S. a particularly strong recovery. In fact, it has been weaker than many previous post-recession rebounds. The White House predicted an average growth of 4 to 4.5 percent and a budget deficit limited to 3.5 percent of GDP. The results are quite different.

1 Reasons against bailouts. Retrieved from [http://bailbondsman10.com/Content41/Reasons-against-bailouts.htm] on $15 / 05 / 2018$. 
During the Obama administration and the implementation of massive expansionary monetary policies, economic growth was only 1.4 percent. This compares to an average 3.5 percent with Reagan, 2.1 percent with Bush Jr. and 3.9 percent with Clinton. After a massive \$25 trillion stimulus, public debt has ballooned to 107 percent of GDP and average annual deficit is 5.2 percent of GDP. To top it all, the U.S. annual productivity growth in the last five years has been 0.6 percent on average, the poorest since 1978. The recovery from the 2008 crash has been painfully slow and unusually weak. According to the Bureau of Economic Analysis, it took nearly four years for U.S. GDP to regain its late 2007 level. By contrast, in the sharp Reagan-era slump, the recovery took just twentyone months. As of early 2016, the total value added for the U.S. economy was barely 10 percent higher than before the 2008 crash. The situation is even more dull with respect to real per capita output. It took the U.S. until mid-2014 to return to its late 2007 per capita output production levels. It seems that America has suffered something close to a "lost decade". Current U.S. economy is not nearly on track to return to its historic growth patterns (Gordon, 2016). A period of what might be described as mild economic growth has somehow produced more wealth for its wealth-holders, with the rise of financial assets, and less work for its workers, with the deterioration of labor figures.

Unconventional monetary policies facilitated what could be called "zombie economics". When the central bank announces the willingness to buy an unlimited amount of government bonds of fiscally distressed countries, these ones stop implementing structural reforms. Instead, they abandon themselves to this massive monetary policies without solving the numerous dysfunctions. Also the banks with significant holdings of those government bonds experience gains from the resulting increase in the bonds' value. Those banks then increase lending to existing borrowers with low creditworthiness and not to high-quality new borrowers. Unconventional monetary policies, then, prevent the liquidation of non-viable businesses and stop public reforms. QE also props up low value activities that never would have existed without an artificially low interest rate. Central bankers risked saddling the economy with debt-burdened banks, governments, businesses and consumers that should be allowed to go bust. With QE you get zombie banking, governments, corporates and households that damage the society in the long run. This situation is connected with the so-called productivity puzzle: output per hour is significantly lower than it would have been had the pre-2008 growth trend continued. The figures are clear across the OECD countries. Output per hour in France was $14 \%$ lower in 2015 than it would have been had the previously normal trend growth rate been matched. Output was $9 \%$ lower in the US and $8 \%$ lower in Germany, which has remained the top performer among developed economies. If this lower growth rate persists, by 2021 average incomes in the U.S. will be $16 \%$ lower than they would have been had the country maintained the roughly $2 \%$ annual productivity gain experienced since 1945. This is because ultra-low interest rates keep some firms above water, and their managers retain employees, despite making a relatively low return. On the other hand, new, more productive, and innovative firms find it hard to raise the capital they need to grow, so they do not expand. In other words, low interest rates hold productivity down by allowing heavily indebted zombie companies to survive for longer than they otherwise would do. The Bank of England has estimated that productivity would have been $1 \%$ to $3 \%$ higher in the U.K. had it raised interest rates to pre-crisis levels in the recovery phase (Haldane, 2016). Sustained policy of exceptionally low interest rates, reinforced by huge doses of QE, has caused asset prices to rise indiscriminately. That has not only had adverse consequences for the distribution of wealth; with quantitative easing, capital markets don't distinguish between productive, high-potential firms and others that deserve to fail. On the other hand, public authorities tend to focus more on investor protection than on the allocational efficiency of the markets they oversee. Investor protection is important, of course, but the primary role of the capital market is the allocation of ownership of the economy's capital stock (Fama, 1970). A regulator focused on that objective would be especially rigorous in overseeing the transparent disclosure of information, and would seek to promote vigorous competition among companies and also, crucially for this objective, among investors. It should not be acceptable for asset managers to earn extravagant returns for following a market benchmark.

\subsection{Jobs}

Finally, in terms of job creation, the fourth objective, 9.3 million jobs created in the US are far from what is expected after a \$25 trillion fiscal and monetary stimulus. Under President Clinton, 21 million jobs were created. Even with crisis, President Reagan saw 12.6 million jobs created. More than 11 million people are out of the labour force in the world's leading economy (Dalirazar, 2007). The implied employment deficit works out to around 1.2 million for men in their early twenties and about 5.5 million for prime-age twenty-five to fifty-four, with the remainder being men in their late fifties and early sixties. Romans used the word "decimation" to describe the loss of a tenth of a given unit of men. 
The United States has suffered something akin to a decimation of its male workforce over the past fifty years. Unlike the dead soldiers in Roman antiquity, the decimated men still live, though in an existence without productive economic purpose. We might say those many millions of men without work constitute a sort of invisible army lost in an overlooked, modern-day depression. And demographics is not the cause (Eberstadt, 2012). The United Kingdom and the United States have similar demographics. Yet the latter's labor force participation is almost ten points lower. Labor force participation rate has fallen in almost all segments of age, including the segment of 25 to 35 years. A total of 94.6 million working-age Americans are not looking for a job. The labor participation rate stands at only 62.8 percent, while employment to population ratio was 59.7 percent in November 2016. Temporary employment stands at 18.2 percent, a recessionary level. Let's consider that in the recession of 2001 it was 17 percent and in 2008 was 20 percent. It does mean that, after the biggest stimulus in history, temporary employment has only reduced a meager 1.8 percent, even with the poor labor participation. In 2015, the work rate for American males aged twenty-five to fifty-four was lower than it had been in 1940, which was at the tail end of the Great Depression. Under today "full employment", a monthly average of nearly one in six prime-age men had no paying job of any kind. Furthermore, the work rate for American men is manifestly lower today than it was in 1930 (Juhn, 1992). Until some years ago, to be jobless was to court financial disaster, and the specter of long term joblessness was terrifying to anyone responsible for supporting a family. In today's America, by contrast, the taxonomy of employment has changed. There are now not two but three possible work categories: employed, unemployed but seeking work, and neither working nor seeking work. A life without work has become a viable option for today's prime-age male. And the facts suggest that once a prime-age man removes himself from the labor force, there is an increasing chance he will remain an un-worker for a long time. To a distressing degree, these men appear to have relinquished what we think of ordinarily as adult responsibilities not only as breadwinners but as parents, family members, community members, and citizens. Having largely freed themselves of such obligations, they fill their days in the pursuit of more immediate sources of gratification. While a minority involves in training or further education pursuing a vocation in life, the vast majority cannot be so described.

\section{Conclusions}

To conclude, the consequences of unconventional monetary policies are mainly negative. QE program has not restored soundness to the economy. QE has not addressed, but exacerbated, the problems caused by central banks manipulating interest rates, determining the money supply, and monetizing government debt and other financial assets. QE has overproduced monetary liquidity, without solving solvency problems, creating an asset inflation and, most remarkably, a massive debt bubble that threatens next generations. It impedes creative destruction allowing companies that no longer generate enough income to pay a positive return on capital to continue as usual rather than being restructured. Zombie companies proliferate, as well as unreasonable leverage and debt ratios (Kashyap, 2002; Krugman, 1998; Svensson, 2006). That damages productivity and the current output per hour is significantly lower than it would have been had the pre-2008 growth trend continued. It also generates artificial winners and losers. The winners are the wealthy with financial assets, but the biggest winner is the state, paying very low interest of a high level of debt and benefiting from taxes on inflated assets. That causes social unrest. The weakened middle class, whose wages have declined for decades, seeks social justice through populist movements. The quantitative easing monetary disruption almost certainly has contributed to the protest votes that have been observed in the Western world. In what refers to employment, although official unemployment rates can be low, labor participation rate and employment to population ratio have not recovered the pre-crisis levels. The massive monetary and fiscal stimuli have not achieved to decrease the temporary employment and, even in a situation of "full employment", nearly one in six prime-age men had no paying job of any kind in the U.S. The funding of a new category consisting in neither working nor seeking work has eroded the moral standard of society. To a distressing degree, many appear to have relinquished what we think of ordinarily as adult responsibilities as family members, community members and citizens. After more than $\$ 25$ trillion of fiscal and monetary expansion, and over 650 rate cuts, the balance of QE is very disappointing. More than $\$ 67$ trillion of global debt created in eight years of stimulus. In five years, to generate $\$ 1$ of growth the G7 have spent $\$ 18$, a third of them coming from central banks. The Bank of England estimates show similar results. In order to spend 1 pound it takes 16 pounds of new money. Then, very little of the money created through QE boosts the real economy. Such ineffectiveness is because it relies on boosting the wealth of the already-wealthy and hoping that they increase their spending, when $40 \%$ of the stock market is owned by the wealthiest $5 \%$ of the population. 
Global debt-to-GDP levels today are some 40 percent higher than they were on the eve of the 2008 global market meltdown. Equally troubling is that debt levels have increased by even larger amounts in a number of systemically important countries. Since 2008, overall debt-to-GDP levels are up by 190 percent in China, by 70 percent in Canada and France, and by 50 percent in Japan. The Bank for International Settlements is also warning that credit-to-GDP gaps have reached levels signaling elevated risks in a number of important emerging market economies. Central banks can either get serious about normalizing interest rates from their artificially low levels or, alternately, they can delay the normalization process at the risk of creating an even greater debt bubble. That course of action would lead to even greater market disruption when that bubble eventually bursts, as it will inevitably do in the end. Printing fiat currency and expanding the money supply has nothing to do with creating wealth. QE process is more likely to destroy wealth than to create it. The QE programs have undermined sound economic policy and will continue to do so as the consequences of the massive monetary expansion become more evident with the bursting of the bubble economy.

\section{References}

Auerbach, A., Obstfeld, M. (2005). "The Case for Open-Market Purchases in a Liquidity Trap". American Economic Review, Vol. 95, No 1, March 2005.

Bank for International Settlements (2017). "Paradoxical tightening echoes bond market conundrum". Quarterly Review, December 2017. Basel: BIS Publications.

Bernanke, B. (2003). "Some Thoughts on Monetary Policy in Japan", Japan Society of Monetary Economics. Tokyo, Japan, 31 May 2003.

Bernanke, B. (2009). "The Crises and the Policy Response", Stamp lecture at the London School of Economics. London, 13 January 2009.

Bernanke, B., Reinhart C. (2004). "Conducting Monetary Policy at Very Low Short-Term Interest Rates". American Economic Review, Papers and Proceedings, 94(2), 2004, pp. 85-90.

Bullard, J. (2009), "Effective Monetary Policy in a Low Interest Rate Environment". The Henry Thornton Lecture, Cass Business School. London, 24 March 2009.

Caballero R.J., Hoshi T., Kashyap A.K. (2008). "Zombie Lending and Depressed Restructuring in Japan". American Economic Review, Vol. 98, No 5, December 2008.

Dalirazar, N. (2007). "Reasons People Do Not Work: Household Economic Studies". Current Population Reports.

Eberstadt, N. (2012). A Nation of Takers: America's Entitlement Epidemic. Montgomery, Pennsylvania: Templeton Press.

Eggertsson, G.B., Woodford, M. (2003). "The Zero Bound on Interest Rates and Optimal Monetary Policy". Brookings Papers on Economic Activity, 2003, No 1, 139-211.

Eggertsson, G.B., Woodford, M. (2004). "Policy Options in a Liquidity Trap". American Economic Review, Papers and Proceedings 94, May 2004, 76-79.

Fama, E. (1970). "Efficient Capital Markets: A Review of Theory and Empirical Work". The Journal of Finance, Vol. 25, No. 2, pp. 383-417. New York: Blackwell Publishing for the American Finance Association.

Feldstein, M. (2016). "The U.S. Economy is in Good Shape”. Wall Street Journal. February 21, 2016.

Franch, J. (2018). "Should we fear deflation? An economic analysis". Journal of Business \& Economic Policy. Vol. 5, No. 1, March.

Gordon, R. (2016). The rise and fall of American growth: the U.S. standard of living since the civil war. Princeton: Princeton University Press.

Haldane, A.G., Sklar, M.R., Wieladek, T., Young, C. (2016). "QE: the story so far". Working Paper, No. 624. London: Bank of England.

Hiroshi, U. (2006). "Effects of the Quantitative Easing Policy: A Survey of Empirical Analyses". Bank of Japan Series, July 2006.

Jeanne, O. and Svensson L. (2007). "Credible Commitment to Optimal Escape from Liquidity Trap: The Role of the Balance Sheet of an Independent Central Bank". American Economic Review, Vol. 97, No 1, March 2007.

Juhn, Ch. (1992). "Decline of Male Labor Market Participation: The Role of Declining Market Opportunities". The Quarterly Journal of Economics. Vol. 107, No. 1, February. 
Kashyap, A. (2002). “Sorting out Japan's financial crisis”, Economic Perspectives 4Q/2002, Federal Reserve Bank of Chicago.

Krugman, P. (1998). "It's Back! Japan's Slump and the Return of the Liquidity Trap". Brookings Papers on Economic Activity, pp. 137-187.

Lacalle, D. (2014). La madre de todas las batallas. Bilbao: Deusto Ediciones.

Paul, R., Lehrman, L. (2007). The case for gold. Alabama: The Ludwig von Mises Institute.

Reinhart, C., Rogoff, K. (2014). "Recovery from Financial Crises: Evidence from 100 Episodes". American Economic Review, Papers and Proceedings 104, No. 5.

Stella, P. (2005). "Central Bank Financial Strength, Transparency and Policy Credibility". IMF Staff Papers $52(2)$.

Summers, L. (2014). "U.S. Economic Prospects: Secular Stagnation, Hysteresis, and the Zero Lower Bound". Business Economics 49, No. 2.

Svensson, L. (2006). “Monetary Policy and Japan's Liquidity Trap”. CEPS Working Paper No. 126. Princeton University. 